\title{
Essential Practices for Instructional Leadership in the Implementation of Elementary Science and Technology Education from Preservice Teachers' Perspective
}

\author{
Zulkefli Daud \\ Department of Science and Mathematics, \\ Institute of Teacher Education, Tun Hussein Onn Campus, \\ 83000 Batu Pahat, Johor, Malaysia \\ zulmydinamik@yahoo.com \\ Noorafizah Daud \\ Faculty of Education, \\ National University of Malaysia, \\ 43600 UKM Bangi, Selangor, Malaysia \\ apit_119@yahoo.com \\ Zainab Ari \\ Sekolah Menengah Kebangsaan Tunku Mahmood Iskandar, \\ Ministry of Education Malaysia, \\ 83200 Senggarang, Batu Pahat, Johor, Malaysia \\ zainab63@gmail.com
}

\author{
Zamidi Ismail \\ Department of Science and Mathematics, \\ Institute of Teacher Education, Tun Hussein Onn Campus, \\ 83000 Batu Pahat, Johor, Malaysia \\ zamidi@iptho.edu.my \\ Abu Bakar Kassim \\ Department of Science and Mathematics, \\ Institute of Teacher Education, Tun Hussein Onn Campus, \\ 83000 Batu Pahat, Johor, Malaysia \\ abubakar@iptho.edu.my
}

implications for instructional leadership management and other responsible agencies to develop personal and professional development among teachers particularly empowering instructional leadership in the elementary science and technology education.

Keywords-Instructional leadership practices, elementary science and technology education, preservice teacher

\section{INTRODUCTION}

The 21st century is an era of globalization that requires all countries to compete with each other to achieve progress. Science and Technology (S\&T) education is crucial in the development of globalization, which it might be able to provide future economic prosperity and ability to become an innovation nation for a country depends on the successful exploitation of S\&T. [1,2] Thus, S\&T is given great emphasis in education system as mention in the national science education philosophy [3], even with the emergence of new teaching and learning approach through the integration of science, technology, engineering and mathematics (STEM). However, no matter what kind of integrating education model that is implemented in our education system either S\&T alone or STEM, empowering instructional leadership is essential to establish relevant and appropriate students for global development in the $21 \mathrm{st}$ century. Accordingly, school organization need to have an effective leader to administer changes particularly related to essential practices for instructional leadership. 
Some education issues related to instructional leadership such as distribution of school leaders in the subject areas, students achievement and interest in S\&T and the transformation of education system can influence the way how the instructional leaders work. Spillane et al. [4] stated that school leadership is usually distributed by subject area. This means the quality of instructional leadership for subject will be different from quality of instructional leadership for other subject areas. Instructional leaders may be questionable in terms of its efficiency if it leads not in the subject field. Besides that, interest in S\&T studies in many countries is falling or at least not developing as rapidly as expected or planned. [5] Likewise, a majority of Malaysian high school students, whose interest in science subjects has been steadily falling. [6] The number of science stream students has dropped up to $29 \%$ since 2007. [7] These findings reflect broader concerns that declining interest of students in science may stunt the efforts to improve the quality of scientific teaching and creativity. Instructional leaders must be able to help teachers use the best practices of effective teaching strategies. [8]

To date, the instructional leaders also need to be aware that they should change at first in order to maintain the transformation at school and demonstrate this change to his surroundings. With this developing and changing education system, the roles expected from instructional leaders have become more complicated. It is more complicated with the concept of socially distributed instructional leadership accounts for the notion that multiple players influenced by their cultural values, gender, race, class, social status and geography. Therefore, effective instructional leadership practices and their potential in taking the right solution in the elementary S\&T education should be emphasized as early as possible to the teachers. It is important to understand the preservice teachers' perspective on the essential practices of instructional leadership in the implementation of elementary S\&T education. Any arising problems before becoming an inservice teachers can be addressed early in order to produce a great future instructional leadership for global development.

\section{A. Science \& Technology (S\&T) Education}

Studies on instructional leadership practices in the elementary S\&T mostly are related to science education. This may be due to elementary science education in many countries including Malaysian science curriculum contained integration topics of S\&T. However, S\&T education at secondary level is more pronounced with the list of S\&T subjects such as Biology, Chemistry, Physic, Additional Mathematics, Additional Science, Technical Communication, Graphic, Basic Sustainability Design, Computer Science, Agriculture, Home Science and Sport Science [9]. Accordingly, it can be assumed that S\&T education is a part of science education. The philosophy nurturing the S\&T culture by focusing on the development of individuals who are competitive, dynamic, robust and resilient and able to master scientific knowledge and technological competencies [10].

\section{B. Instructional Leadership Model in S\&T Education}

There were very limited models of instructional leadership practices in the elementary S\&T education. Andrews and Soder [11], Casey et al. [12] and Peacock [13] are several researchers who involved on instructional leadership research in science education.

Commonly the first key area of instructional leadership in any field is the school leader who guides the school community, especially the faculty, in the scope of curriculum innovation in the field of subject [14]. Further, the leader can manage resources for the implementation of subject curricula including professional development and fundamental technology systems. Lastly, the leader can manage to build an incentive and rewards program to motivate faculties and students in teaching and learning subjects. Hallinger and Murphy [15], Murphy [16] and Hallinger [17] stated that instructional leadership is operationalized as defining and communicating the school's mission, managing the school's instructional program by supervising and evaluating instruction, coordinating the curriculum and monitoring student progress and creating a learning climate, protecting teacher instructional time and providing incentives for learning.

Based on all models of instructional leadership suggested by many researchers, it is important that the instructional leadership practices in any fields basically should contains three dimensions namely i) defining the school goals, ii) managing the instructional program and iii) promoting a positive school learning climate. The first dimension defining the school goals includes two sub dimensions; i) frame school goals and ii) communicates the schools goals. The second dimension managing the instructional program has three sub dimensions; i) coordinates the curriculum, ii) supervises and evaluates instruction and iii) monitors students progress. The third dimension promoting a positive school learning climate has five subdimensions; i) protects instructional time, ii) provides incentive for teachers, iii) provides incentive for learning, iv) promotes professional development and v) maintains highly visibility. validated by Ibrahim and Wan Muhammad Amin. [18] Most of research studies were conducted on practices behavior of principals, apparently no report study was found from pre-service teachers perceptions on essential practices for instructional leadership. Hence, researchers investigated the three dimensions and the ten sub dimensions of instructional leadership from pre-service teachers perspective.

\section{OBJECTIVES \& QUESTIONS OF THE STUDY}

This study was designed to investigate the pre-service teachers' perspective on essential practices for instructional leadership in the implementation of elementary S\&T education. Specifically, the study aims to answer the following questions:

a. What is the essential practices for instructional leadership in the implementation of elementary S\&T education from pre-service teachers perspective? 
b. Is there any significant difference between male and female pre-service teachers towards the rating of essential practices for instructional leadership in the implementation of elementary S\&T education?

c. Is there any significant difference among pre-service teachers between Bumiputra ethnic group and nonBumiputra ethnic group towards the rating of essential practices for instructional leadership in the implementation of elementary S\&T education?

d. Is there any significant difference among pre-service teachers between majored in science and technology and majored in non science and technology towards the rating of essential practices for instructional leadership in the implementation of elementary S\&T education?

This study tests the following null hypotheses:

a. There is no significant difference between male and female pre-service teachers towards the rating of essential practices for instructional leadership in the implementation of elementary $S \& T$ education.

b. There is no significant difference among pre-service teachers between Bumiputra ethnic group and nonBumiputra ethnic group towards the rating of essential practices for instructional leadership in the implementation of elementary S\&T education.

c. There is no significant difference among pre-service teachers between majored in science and technology and majored in non science and technology towards the rating of essential practices for instructional leadership in the implementation of elementary S\&T education.

\section{METHODOLOGY}

In this study, the population ( $\mathrm{N}=160$ respondents) was all pre-service teachers who are in the third semester at one of the educational institutions in Malaysia in the academic year of 2016. The third semester pre-service teachers were selected because they were the first cohort studies under the new curriculum in undergraduate education. Considering the small number of population, all the third semester pre-service teachers were the targeted respondents. Questionnaires were distributed to them, but only 141 completed questionnaires were returned. Using the sample size calculator, sample size, $\mathrm{n}=141$ respondents and population size, $\mathrm{N}=160$ respondents, it gave a margin of error of about $2.85 \%$ at $95 \%$ confidence level. [19] Usually, it is common to take a margin of error of $5 \%$ and confidence level of $95 \%$. Therefore, the result of this calculation has complied with the optimal sample size for the survey.

The total of 141 pre-service teachers was participated in this study. It consisted of 40 (39.6\%) males and 101 (61.4\%) females with similar age about 20 years. Ninety eight $(69.5 \%)$ were Bumiputra ethnic, while 43 (31.5\%) were nonBumiputra ethnic. In this study, Bumiputra refers to the indigenous people or "sons of the soil" including the predominant Malays and the other native people of Sabah and Sarawak. The other races in Malaysia such as Chinese and Indians refers to nonBumiputra. Respondents were also divided into two groups of courses, 67 (47.5\%) respondents majored in science and technology and $74(52.5 \%)$ respondents majored in non science and technology. These demographic profiles may reflect an important background of sample which could affect their perspectives on essential practices for instructional leadership.

This study used the survey approach using a questionnaire with a 5-point Likert scale as a data collection tool. The questionnaire was designed and adapted by researchers to investigate the essential practices for instructional leadership management in the implementation of elementary S\&T education. It contained a combination of researchers own questions and adapted questions. Cronbach's alpha for the scale was calculated to be 0.81 . Construction of questionnaire also referred to the high reliability and validity of the principal instructional leadership questionnaire such as developed by Pettiegrew II [20], Owens [21], Gumuseli [22], Kapusuzoglu and Baysal [23], Murphy and Hallinger [24] and Jawas [25]. The questionnaire had 60 items under main three dimensions with 10 sub dimensions. Table 1 shows the dimension and sub dimension of instructional leadership.

Table 1: Dimension and sub dimension of instructional leadership

\begin{tabular}{|c|c|c|c|}
\hline & Dimension & & Sub dimension \\
\hline A & $\begin{array}{l}\text { Defining the } \\
\text { school goals }\end{array}$ & $\begin{array}{l}\text { I } \\
\text { II }\end{array}$ & $\begin{array}{l}\text { Frames school goals } \\
\text { Communicates the schools goals }\end{array}$ \\
\hline B & $\begin{array}{l}\text { Managing the } \\
\text { instructional } \\
\text { program }\end{array}$ & $\begin{array}{l}\text { III } \\
\text { IV } \\
\text { V }\end{array}$ & $\begin{array}{l}\text { Coordinates the curriculum } \\
\text { Supervises and evaluates instruction } \\
\text { Monitors students progress }\end{array}$ \\
\hline $\mathrm{C}$ & $\begin{array}{l}\text { Promoting a } \\
\text { positive school } \\
\text { learning climate }\end{array}$ & $\begin{array}{l}\text { VI } \\
\text { VII } \\
\text { VIII } \\
\text { IX } \\
X\end{array}$ & $\begin{array}{l}\text { Protects instructional time } \\
\text { Provides incentive for teachers } \\
\text { Provides incentive for learning } \\
\text { Promotes professional development } \\
\text { Maintains highly visibility }\end{array}$ \\
\hline
\end{tabular}

In order to measure these rated dimension and sub dimensions, the scale with five degrees; (5) Strongly agree $(\mathrm{X}=4.20-5.00)$, (4) Agree $(\mathrm{X}=3.40-4.19)$, (3) Moderate $(\mathrm{X}=2.60-3.39)$, (2) Disagree $(\mathrm{X}=1.80-2.59)$ and (1) Strongly disagree $(X=1.00-1.79)$ were used. The data analyses were made by t-test. Significance level was taken to be 0.05 . All data were analyzed using SPSS 15.0 package program.

\section{RESULTS AND DISCUSSION}

The first research question in this study was "what is the essential practices for instructional leadership in the implementation of elementary S\&T education from preservice teachers perspective?". To answer this question, Table 2 and Table 3 summarizes the mean rating level of essential practices for instructional leadership from pre-service teachers perceptions of each dimensions and sub dimensions of the instructional leadership management rating scale. The essential practices for instructional leadership have been analyzed in terms of mean (X) and standard deviation (s.d.). It was divided into 3 dimensions and 10 sub dimensions of instructional leadership.

The rated sub dimension for instructional leadership showed that all the results were above 4 mean score. These results indicate that all sub dimensions of instructional leadership either "agree" or "strongly agree" to practice in the 
implementation of elementary S\&T education. This suggests that pre-service teachers are aware of the importance of instructional leadership for the success of their schools, and are attempting to demonstrate these behaviors consistently in at least 4 mean score of the leadership sub dimensions. The top five highly rated sub dimensions namely; "maintains highly visibility" $(X=4.292 \pm 0.478)$, "communicates the schools goals" $(\mathrm{X}=4.255 \pm 0.455)$, "provides incentive for learning" $(X=4.227 \pm 0.472)$, "promotes professional development" $(\mathrm{X}=4.214 \pm 0.433)$ and "monitors students progress" $(X=4.211 \pm 0.455)$ also showed that these sub dimensions were the most important essential practices for instructional leadership.

The first sub dimension, "frames school goals" was rated $X=4.173 \pm 0.502$, while second sub dimension, "communicates the schools goals" was rated above 4.2 mean score as mentioned previously. Although, first sub dimension is slightly low compared to second sub dimension but both sub dimensions with mean score above 4 are in accordance with the important mediating factors for successful schools as revealed by Hallinger and Heck [26] and Robinson [27].

Other sub dimensions, like "coordinates the curriculum" $(X=4.145 \pm 0.482)$, "supervises and evaluates instruction", $(X=4.155 \pm 0.477)$, "protects instructional time", $(X=4.162$ $\pm 0.498)$ and "provide incentives for teachers", $(X=4.179$ \pm 0.476 ) were also rated below 4.2 mean score. According to Robinson [27] these 4 sub dimensions had a significant impact on students achievement. Mamano et al. [28] also stated that protecting instructional time from interruptions is a primary role of the principal. In this study, the "coordinates the curriculum" was not only the lowest rated sub dimension but it was also the lowest rated dimension. This finding is significant because it indicates that pre-service teachers actually requires more training to acquire skills in instructional leadership particularly in the curriculum target.

In general, high rated of all sub dimensions in this findings above 4 mean score are consistent with most actual instructional leadership practices by instructional leaders from teachers perceptions in effective school and high performance students. [29]

For dimensions, the highest rated dimension in this study was "promoting a positive school learning climate", $X=4.215 \pm 0.398$, whereas the lowest rated dimension as mentioned earlier was "managing the instructional program", $X=4.170 \pm 0.419$. The overall essential practices for instructional leadership from pre-service teachers perspective was highly rated on the three dimensions studied with an overall mean, $X=4.201 \pm 0.379$. This finding is also accordance with actual practices by instructional leadership for effective principal [30] and in effective school [31,32]. However, in this study "managing the instructional program" showed lowest rated of essential practices, thus this result is important when consider the current initiatives taken by instructional leadership management or other responsible agencies to develop the education system and improve its quality. This finding is quite difficult to compare with other studies because most research focused on the behavior of instructional leadership practices but this study focused on the practices to be implemented by instructional leadership.

Table 2: Mean score, standard deviation and rating level of sub dimension

\begin{tabular}{|ll|l|l|}
\hline \multicolumn{1}{|c|}{ Dimension } & $\begin{array}{c}\text { Mean, X } \\
\text { and s.d. }\end{array}$ & \multicolumn{1}{|c|}{ Level } \\
\hline I & Frames school goals & $4.173 \pm 0.502$ & agree \\
11 & Communicates the schools goals & $4.255 \pm 0.445$ & strongly agree \\
111 & Coordinates the curriculum & $4.145 \pm 0.482$ & agree \\
1V & Supervises and evaluates instruction & $4.155 \pm 0.474$ & agree \\
V & Monitors students progress & $4.211 \pm 0.445$ & strongly agree \\
VI & Protects instructional time & $4.162 \pm 0.498$ & agree \\
VII & Provides incentive for teachers & $4.179 \pm 0.476$ & agree \\
VIII Provides incentive for learning & $4.227 \pm 0.472$ & strongly agree \\
IX & Promotes professional development & $4.214 \pm 0.433$ & strongly agree \\
X & Maintains highly visibility & $4.292 \pm 0.478$ & strongly agree \\
\hline
\end{tabular}

Table 3: Mean score, standard deviation and rating level of dimension

\begin{tabular}{|l|l|l|}
\hline \multicolumn{1}{|c|}{ Dimension } & $\begin{array}{c}\text { Mean, X and } \\
\text { s.d. }\end{array}$ & Level \\
\hline A Defining the school goals & $4.214 \pm 0.426$ & strongly agree \\
\hline B Managing the instructional program & $4.170 \pm 0.419$ & agree \\
\hline $\begin{array}{c}\text { C Promoting a positive school learning } \\
\text { climate }\end{array}$ & $4.215 \pm 0.398$ & strongly agree \\
\hline \multicolumn{1}{|c|}{ Overall } & $4.201 \pm 0.379$ & strongly agree \\
\hline
\end{tabular}

The second research question, which is a combination of three questions was "Is there any significant differences between gender, races and courses among preservice teachers towards the rating of essential practices for instructional leadership in the implementation of elementary S\&T education?" To address this question, the distribution of rating overall essential practices from preservice teachers perspectives and their t-test based on gender, races and courses are shown in Table 4.

Table 4: T-test on overall essential practices for instructional leadership

\begin{tabular}{|l|l|l|l|l|l|l|}
\hline $\begin{array}{l}\text { Demographic } \\
\text { profile }\end{array}$ & $\mathrm{n}$ & $\mathrm{X}$ & s.d. & $\mathrm{df}$ & $\mathrm{T}$ & $\mathrm{P} . \mathrm{sig}$ \\
\hline Male & 40 & 4.134 & 0.343 & 139 & - & 0.210 \\
Female & 101 & 4.227 & 0.391 & & 1.261 & \\
\hline Bumiputra & 98 & 4.278 & 0.382 & 139 & 3.776 & $0.000^{*}$ \\
nonBumiputra & 43 & 4.027 & 0.310 & & & \\
\hline $\begin{array}{l}\text { S\&T } \\
\text { non S\&T }\end{array}$ & 67 & 4.525 & 0.351 & 139 & 1.509 & 0.134 \\
\hline
\end{tabular}

As shown in Table 4, females $(X=4.227 \pm 0.391)$ showed higher rated on the essential practices for instructional leadership in the implementation of elementary S\&T education compared with males $(X=4.143 \pm 0.343)$. Respondents majored in $\mathrm{S} \& \mathrm{~T}(\mathrm{X}=4.525 \pm 0.351)$ also showed higher rated of essential practices for instructional leadership in the implementation of elementary S\&T education compared with respondents majored in nonscience and technology $(X=4.156 \pm 0.399)$. For the racial, the nonBumiputra ethnic group $(X=4.027 \pm 0.310)$ showed lower rated on the essential practices for instructional leadership compared with Bumiputra ethnic group $(X=4.278 \pm 0.382)$. In order to test 
whether the mean scores were statistically significant or not between gender, races and courses, t-test were conducted.

T-test of this study found that there were no significant differences between gender and courses towards all dimensions. This means that gender and courses of different groups did not affect the mean scores level of dimensions rated. This result also indicated that the score of the different gender and courses groups regarding their perception towards all rated dimensions not differ from each other. This may be due to the pre-service teachers of all gender and courses group have been exposed to a similar conceptual framework on essential practices for instructional leadership in their teaching and learning activities provided by their institution and during practical by elementary school management. This findings were consistent with the results of overall mean scores (X) and t-test for each main dimensions as shown in Table 5. In this analysis, there were no statistically significant differences between gender and courses for each of the three main dimensions. The first and second null hypothesis stated that there is no statistically significant differences between gender and courses in the rating of essential practices for instructional leadership in the implementation of elementary S\&T education. As was stated previously, this null hypothesis was not rejected on the basis that statistically significant differences were not found between gender and courses.

However, the t-test for racial groups found that there were significant differences between Bumiputra and nonBumiputra ethnic group towards the overall essential practices for instructional leadership, $\mathrm{t}(139)=3.776, \mathrm{p}=0.000$.

Table 5: Overall mean scores (X) and t-test for dimensions (D)

\begin{tabular}{|l|l|l|l|l|l|l|l|}
\hline $\mathrm{D}$ & $\begin{array}{l}\text { Demographic } \\
\text { profile }\end{array}$ & $\mathrm{n}$ & $\mathrm{X}$ & $\mathrm{s} . \mathrm{d}$ & $\mathrm{df}$ & $\mathrm{t}$ & P.sig. \\
\hline \multirow{5}{*}{$\mathrm{A}$} & Male & 40 & 4.123 & 0.387 & 139 & -1.617 & 0.108 \\
& Female & 101 & 4.251 & 0.437 & & & \\
\cline { 2 - 8 } & Bumiputra & 98 & 4.293 & 0.449 & 139 & 3.436 & $0.001^{*}$ \\
& nonBumiputra & 43 & 4.035 & 0.305 & & & \\
\cline { 2 - 9 } & S\&T & 67 & 4.243 & 0.484 & 139 & 0.771 & 0.442 \\
& non S\&T & 74 & 4.188 & 0.433 & & & \\
\hline \multirow{5}{*}{$\mathrm{B}$} & Male & 40 & 4.107 & 0.390 & 139 & -1.134 & 0.259 \\
& Female & 101 & 4.195 & 0.429 & & & \\
\cline { 2 - 8 } & Bumiputra & 98 & 4.237 & 0.424 & 139 & 2.953 & $0.004^{*}$ \\
& nonBumiputra & 43 & 4.017 & 0.368 & & & \\
\cline { 2 - 8 } & S\&T & 67 & 4.211 & 0.384 & 139 & 1.099 & 0.274 \\
& non S\&T & 74 & 4.133 & 0.447 & & & \\
\hline \multirow{5}{*}{$\mathrm{C}$} & Male & 40 & 4.162 & 0.359 & 139 & -0.989 & 0.324 \\
& Female & 101 & 4.236 & 0.413 & & & \\
\cline { 2 - 8 } & Bumiputra & 98 & 4.296 & 0.397 & 139 & 3.805 & $0.000^{*}$ \\
& nonBumiputra & 43 & 4.031 & 0.339 & & & \\
\cline { 2 - 8 } & S\&T & 67 & 4.279 & 0.374 & 139 & 1.849 & 0.067 \\
& non S\&T & 74 & 4.156 & 0.413 & & & \\
\hline
\end{tabular}

$* \mathrm{p}<0.05$

Analysis of the main dimensions also found similar findings (Table 5), where the results found the significant differences between Bumiputra and nonBumiputra ethnic group towards the "defining the school goals" $(\mathrm{t}(139)=3.436$, $\mathrm{p}=0.001)$, "managing the instructional program" $(\mathrm{t}(139)=2.953, \mathrm{p}=0.004)$ and "promoting a positive school learning climate" $(\mathrm{t}(139)=3.805, \mathrm{p}=0.000)$. Results may reflect that each race has a different personal hold values in leadership roles. This result also indicates that scores of different racial groups regarding their perception towards on essential practices for instructional leadership differ from each other. The third null hypothesis stated that there is no statistically significant differences between races in the rating of essential practices for instructional leadership in the implementation of elementary S\&T education. As was stated previously, this null hypothesis was rejected on the basis that statistically significant differences were found between races.

Analysis mean scores and t-test of each sub dimension in this study was also conducted as shown in Table 6, Table 7 and Table 8. Mean scores (X) of "frames school goals" and "communicates school goals" based on gender, races and courses was more than 4 mean score. This means subdimensions were "agree" or "strongly agree" to practice for instructional leadership. As in dimensions, there was no significant difference between gender and courses towards the subdimensions rated and significant difference only found between races. Bumiputra ethnic group has very different perceptions on essential practices of subdimensions, "defining the school goals" compared to nonBumiputra ethnic group. Similar results also found for subdimension in dimension 2 (Table 7) and 3 (Table 8).

Table 6: Mean scores $(\mathrm{X})$ and t-test for subdimensions $(\mathrm{S})$ in first dimension

\begin{tabular}{|c|c|c|c|c|c|c|c|}
\hline $\mathbf{S}$ & $\begin{array}{l}\text { Demographic } \\
\text { profile }\end{array}$ & $\mathbf{n}$ & $\mathbf{X}$ & s.d. & df & $\mathbf{T}$ & P.sig. \\
\hline \multirow{3}{*}{ I } & $\begin{array}{l}\text { Male } \\
\text { Female }\end{array}$ & $\begin{array}{l}40 \\
101\end{array}$ & $\begin{array}{l}4.070 \\
4.214\end{array}$ & $\begin{array}{l}0.517 \\
0.492\end{array}$ & 139 & -1.543 & 0.125 \\
\hline & $\begin{array}{l}\text { Bumiputra } \\
\text { nonBumiputra }\end{array}$ & $\begin{array}{l}98 \\
43\end{array}$ & $\begin{array}{l}4.233 \\
4.037\end{array}$ & $\begin{array}{l}0.537 \\
0.381\end{array}$ & 139 & 2.158 & $0.033^{*}$ \\
\hline & $\begin{array}{l}\text { S\&T } \\
\text { non S\&T }\end{array}$ & $\begin{array}{l}67 \\
74\end{array}$ & $\begin{array}{l}4.209 \\
4.141\end{array}$ & $\begin{array}{l}0.489 \\
0.514\end{array}$ & 139 & 0.808 & 0.421 \\
\hline \multirow{3}{*}{ II } & $\begin{array}{l}\text { Male } \\
\text { Female }\end{array}$ & $\begin{array}{l}40 \\
101\end{array}$ & $\begin{array}{l}4.175 \\
4.287\end{array}$ & $\begin{array}{l}0.368 \\
0.470\end{array}$ & 139 & -1.352 & 0.179 \\
\hline & $\begin{array}{l}\text { Bumiputra } \\
\text { nonBumiputra }\end{array}$ & $\begin{array}{l}98 \\
43\end{array}$ & $\begin{array}{l}4.353 \\
4.033\end{array}$ & $\begin{array}{l}0.461 \\
0.311\end{array}$ & 139 & 4.157 & $0.000 *$ \\
\hline & $\begin{array}{l}\text { S\&T } \\
\text { non S\&T }\end{array}$ & $\begin{array}{l}67 \\
74\end{array}$ & $\begin{array}{l}4.278 \\
4.235\end{array}$ & $\begin{array}{l}0.437 \\
0.456\end{array}$ & 139 & 0.564 & 0.574 \\
\hline
\end{tabular}

$* \mathrm{p}<0.05$

Table 7: Mean scores (X) and t-test for subdimensions (S) in second dimension

\begin{tabular}{|c|c|c|c|c|c|c|c|}
\hline $\mathbf{S}$ & $\begin{array}{l}\text { Demographic } \\
\text { profile }\end{array}$ & $\mathbf{n}$ & $\mathbf{X}$ & s.d. & df & $\mathbf{T}$ & P.sig. \\
\hline \multirow{3}{*}{ III } & $\begin{array}{l}\text { Male } \\
\text { Female }\end{array}$ & $\begin{array}{l}40 \\
101\end{array}$ & $\begin{array}{l}4.060 \\
4.178\end{array}$ & $\begin{array}{l}0.416 \\
0.504\end{array}$ & 139 & -1.315 & 0.191 \\
\hline & $\begin{array}{l}\text { Bumiputra } \\
\text { nonBumiputra }\end{array}$ & $\begin{array}{l}98 \\
43\end{array}$ & $\begin{array}{l}4.198 \\
4.023\end{array}$ & $\begin{array}{l}0.503 \\
0.412\end{array}$ & 139 & 2.001 & $0.047 *$ \\
\hline & $\begin{array}{l}\text { S\&T } \\
\text { non S\&T }\end{array}$ & $\begin{array}{l}67 \\
74\end{array}$ & $\begin{array}{l}4.149 \\
4.141\end{array}$ & $\begin{array}{l}0.453 \\
0.510\end{array}$ & 139 & 0.107 & 0.915 \\
\hline \multirow{3}{*}{ IV } & $\begin{array}{l}\text { Male } \\
\text { Female }\end{array}$ & $\begin{array}{l}40 \\
101\end{array}$ & $\begin{array}{l}4.125 \\
4.166\end{array}$ & $\begin{array}{l}0.474 \\
0.475\end{array}$ & 139 & -0.466 & 0.642 \\
\hline & $\begin{array}{l}\text { Bumiputra } \\
\text { nonBumiputra }\end{array}$ & $\begin{array}{l}98 \\
43\end{array}$ & $\begin{array}{l}4.231 \\
3.981\end{array}$ & $\begin{array}{l}0.470 \\
0.438\end{array}$ & 139 & 2.956 & $0.004 *$ \\
\hline & $\begin{array}{l}\text { S\&T } \\
\text { non S\&T }\end{array}$ & $\begin{array}{l}67 \\
74\end{array}$ & $\begin{array}{l}4.221 \\
4.095\end{array}$ & $\begin{array}{l}0.465 \\
0.477\end{array}$ & 139 & 1.590 & 0.114 \\
\hline \multirow{3}{*}{ V } & $\begin{array}{l}\text { Male } \\
\text { Female }\end{array}$ & $\begin{array}{l}40 \\
101\end{array}$ & $\begin{array}{l}4.135 \\
4.242\end{array}$ & $\begin{array}{l}0.445 \\
0.444\end{array}$ & 139 & -1.285 & 0.201 \\
\hline & $\begin{array}{l}\text { Bumiputra } \\
\text { nonBumiputra }\end{array}$ & $\begin{array}{l}98 \\
43\end{array}$ & $\begin{array}{l}4.284 \\
4.047\end{array}$ & $\begin{array}{l}0.456 \\
0.375\end{array}$ & 139 & 2.994 & $0.003 *$ \\
\hline & $\begin{array}{l}\text { S\&T } \\
\text { non S\&T }\end{array}$ & $\begin{array}{l}67 \\
74\end{array}$ & $\begin{array}{l}4.263 \\
4.165\end{array}$ & $\begin{array}{l}0.422 \\
0.463\end{array}$ & 139 & 1.306 & 0.194 \\
\hline
\end{tabular}

This study also found the mean score (X) for nonBumiputra ethnic group on "supervises and evaluates instruction", $(X=3.981 \pm 0.438)$ and "provide incentives for teachers", $(X=3.991 \pm 0.362)$ were not only lower compared to Bumiputra ethnic group but with other demographic profiles. 
Thus, these subdimensions were rated in "low agree" to practice in the implementation of elementary S\&T education. In addition to the values of different personal holdings as stated previously, these results may also be due to the influence of peers and family. Future research is needed to find the concrete reasons of these findings.

Table 8: Mean scores (X) and t-test for subdimensions (S) in third dimension

\begin{tabular}{|c|c|c|c|c|c|c|c|}
\hline $\mathbf{S}$ & $\begin{array}{l}\text { Demographic } \\
\text { profile }\end{array}$ & $\mathbf{n}$ & $\mathbf{X}$ & s.d. & df & $\mathbf{t}$ & P.sig. \\
\hline \multirow{3}{*}{ VI } & $\begin{array}{l}\text { Male } \\
\text { Female }\end{array}$ & $\begin{array}{c}40 \\
101\end{array}$ & $\begin{array}{l}4.060 \\
4.202\end{array}$ & $\begin{array}{l}0.499 \\
0.487\end{array}$ & 139 & -1.550 & 0.123 \\
\hline & $\begin{array}{l}\text { Bumiputra } \\
\text { nonBumiputra }\end{array}$ & $\begin{array}{l}98 \\
43\end{array}$ & $\begin{array}{l}4.233 \\
4.000\end{array}$ & $\begin{array}{l}0.490 \\
0.466\end{array}$ & 139 & 2.635 & $0.009 *$ \\
\hline & $\begin{array}{l}\text { S\&T } \\
\text { non S\&T }\end{array}$ & $\begin{array}{l}67 \\
74\end{array}$ & $\begin{array}{l}4.206 \\
4.122\end{array}$ & $\begin{array}{l}0.492 \\
0.493\end{array}$ & 139 & 1.015 & 0.312 \\
\hline \multirow{3}{*}{ VII } & $\begin{array}{l}\text { Male } \\
\text { Female }\end{array}$ & $\begin{array}{c}40 \\
101\end{array}$ & $\begin{array}{l}4.090 \\
4.214\end{array}$ & $\begin{array}{l}0.430 \\
0.490\end{array}$ & 139 & -1.399 & 0.164 \\
\hline & $\begin{array}{l}\text { Bumiputra } \\
\text { nonBumiputra }\end{array}$ & $\begin{array}{l}98 \\
43\end{array}$ & $\begin{array}{l}4.261 \\
3.991\end{array}$ & $\begin{array}{l}0.497 \\
0.362\end{array}$ & 139 & 3.212 & $0.002^{*}$ \\
\hline & $\begin{array}{l}\text { S\&T } \\
\text { non S\&T }\end{array}$ & $\begin{array}{l}67 \\
74\end{array}$ & $\begin{array}{l}4.257 \\
4.108 \\
\end{array}$ & $\begin{array}{l}0.464 \\
0.478\end{array}$ & 139 & 1.870 & 0.064 \\
\hline \multirow{3}{*}{ VIII } & $\begin{array}{l}\text { Male } \\
\text { Female }\end{array}$ & $\begin{array}{c}40 \\
101\end{array}$ & $\begin{array}{l}4.220 \\
4.230\end{array}$ & $\begin{array}{l}0.472 \\
0.474\end{array}$ & 139 & -0.110 & 0.913 \\
\hline & $\begin{array}{l}\text { Bumiputra } \\
\text { nonBumiputra }\end{array}$ & $\begin{array}{l}98 \\
43\end{array}$ & $\begin{array}{l}4.296 \\
4.070\end{array}$ & $\begin{array}{l}0.498 \\
0.365\end{array}$ & 139 & 2.675 & $0.008^{*}$ \\
\hline & $\begin{array}{l}\text { S\&T } \\
\text { non S\&T }\end{array}$ & $\begin{array}{l}67 \\
74 \\
\end{array}$ & $\begin{array}{l}4.302 \\
4.160 \\
\end{array}$ & $\begin{array}{l}0.470 \\
0.467\end{array}$ & 139 & 1.798 & 0.074 \\
\hline \multirow{3}{*}{ IX } & $\begin{array}{l}\text { Male } \\
\text { Female }\end{array}$ & $\begin{array}{c}40 \\
101\end{array}$ & $\begin{array}{l}4.155 \\
4.238 \\
\end{array}$ & $\begin{array}{l}0.358 \\
0.458\end{array}$ & 139 & -1.022 & 0.308 \\
\hline & $\begin{array}{l}\text { Bumiputra } \\
\text { nonBumiputra }\end{array}$ & $\begin{array}{l}98 \\
43\end{array}$ & $\begin{array}{l}4.292 \\
4.037\end{array}$ & $\begin{array}{l}0.444 \\
0.345\end{array}$ & 139 & 3.331 & $0.001 *$ \\
\hline & $\begin{array}{l}\text { S\&T } \\
\text { non S\&T }\end{array}$ & $\begin{array}{l}67 \\
74\end{array}$ & $\begin{array}{l}4.263 \\
4.170\end{array}$ & $\begin{array}{l}0.422 \\
0.440\end{array}$ & 139 & 1.269 & 0.206 \\
\hline \multirow{3}{*}{$\mathbf{X}$} & $\begin{array}{l}\text { Male } \\
\text { Female }\end{array}$ & $\begin{array}{c}40 \\
101 \\
\end{array}$ & $\begin{array}{l}4.285 \\
4.295 \\
\end{array}$ & $\begin{array}{l}0.437 \\
0.495\end{array}$ & 139 & -0.112 & 0.911 \\
\hline & $\begin{array}{l}\text { Bumiputra } \\
\text { nonBumiputra }\end{array}$ & $\begin{array}{l}98 \\
43\end{array}$ & $\begin{array}{l}4.396 \\
4.056\end{array}$ & $\begin{array}{l}0.466 \\
0.422\end{array}$ & 139 & 4.106 & $0.000^{*}$ \\
\hline & $\begin{array}{l}\text { S\&T } \\
\text { non S\&T }\end{array}$ & $\begin{array}{l}67 \\
74\end{array}$ & $\begin{array}{l}4.370 \\
4.222 \\
\end{array}$ & $\begin{array}{l}0.464 \\
0.483\end{array}$ & 139 & 1.859 & 0.065 \\
\hline
\end{tabular}

To reduce the different perceptions between races, Hawley [33] suggested that strategies involving cooperative interdependence among persons of different races or ethnic groups should be carefully structured to ensure that all participants are encouraged to make useful and valued contributions to the group. Significant differences in the perception of essential practices for instructional leadership among pre-service teachers should be reduced in order to give optimum impact in the implementation of elementary S\&T education.

Based on the results and discussion above, these findings have implications for instructional leadership management and other responsible agencies to develop personal and professional development among teachers in the implementation of elementary S\&T education. Three important implications can be suggested from this study. First, disclosure about essential practices for instructional leadership should be implemented since the early stages of involvement as a teacher in order to reduce the differences in views on the role of leadership, which if not addressed can affect global development in the future. This implication is based on the results of different perceptions of essential practices for instructional leadership in accordance with their respective demographic background. Second, instructional leadership behaviour is important to improve students achievements and school effectiveness [34]. This study found that mean score for all dimensions of instructional leadership were strongly agree to practice in the implementation of elementary S\&T education. However, the challenge is to practice all suggested dimensions during implementation of elementary S\&T education. Instructional leadership qualities should be enhanced to address this issue. Finally, the global development is always related to exploitation of S\&T. S\&T is a key factor in leading the country's competitiveness in the global development [35], thus empowering instructional leadership in the implementation of elementary S\&T education is required. To enhance the instructional leadership skills among teachers and pre-service teachers, courses such as principalship, educational leadership or instructional leadership studies should be developed appropriate to them.

\section{CONCLUSION}

From the results, it could be concluded that the essential practices for instructional leadership namely; "defining the school goals", "managing the instructional program" and "promoting a positive school learning climate" were strongly agree to practice in the implementation of elementary S\&T education. The top five highly rated of essential practices for instructional leadership based on subdimension was "maintains highly visibility", "communicates the schools goals", "provides incentive for learning", "promotes professional development" and "monitors students progress". Statistically significant differences were found between races of pre-service teachers regarding their perceptions of the level of essential practices for instructional leadership in all dimensions. However, there were no significant differences between gender and courses towards the essential practices. Therefore, race should be highlighted when practice the instructional leadership. It is hoped that this study will provide useful findings, particularly to assist the quality of instructional leaders in mastering essential practices for instructional leadership in the implementation of elementary S\&T education in the future.

\section{ACKNOWLEDGMENT}

The authors greatly appreciate everyone from Institute of Teacher Education, Tun Hussein Onn Campus, Batu Pahat, Johor, especially from the Department of Science \& Mathematics that involves directly or indirectly in preparing and accomplishment of this research. The authors also thank to Muhammad Aris Farhan Jamaludin and the first cohort undergraduate students (Elective Science \& Mathematics) for assistance in research survey.

\section{REFERENCES}

[1] Minister of State for Science and Innovation, "A vision for Science and Society: a consultation on developing a new strategy for the UK", Crown, 2008

[2] O. O. Adebile and D. K. Shangodoyin, "The need for science and technology driving forces in sustainable socio-economic development of 
Nigeria”, Journal of Sustainable Development, 2011, 4(4), 132-159, in press.

[3] M. A. H. Bunyamin and F. Finley, "STEM education in Malaysia: reviewing the current physics curriculum", Conference: International Conference of Association for Science Teacher Education, at Reno, Nevada, United States, January 7-9, 2016.

[4] J. P. Spillane, J. B. Diamond and L. Jita, "Leading instruction: the distribution of leadership for instruction", Journal of Curricuilum Studies, 2003, 35(5), 533-43, in press

[5] S. Sjoberg, "Science and technology education: current challenges and possible solutions", in Innovations in Science and Technology Education, Vol VIII, J. Edger, Ed. Paris, UNESCO, 2003, pp 201-228.

[6] F. A. Phang, M. S. Abu, M. B. Ali and S. Salleh, "Faktor penyumbang kepada kemerosotan penyertaan pelajar dalam aliran sains", Sains Humanika, 2014, 2(4), 63-71. in press.

[7] A. Ayob, "Ways to increase student interest in science and mathematics: cara meningkatkan minat pelajar terhadap sains dan matematik", Paper presented in Colloquium on Mathematics and Science Education, Universiti Malaya, 2012

[8] C. Barrett and R. Breyer, "The Influence of effective leadership on teaching and learning", Journal of Research Initiatives, 2014, 1(2), 1-9. in press.

[9] Curriculum Development Division, Ministry of Education Malaysia, "Sharing Malaysian experience in participation of girls in stem education. In-progress reflection no. 3 on current and critical issues in curriculum and learning", Geneva, Switzerland, UNESCO International Bureau of Education (IBE), 2016.

[10] M. F. Mat Salleh, N. Abdullah, N. A. Alias and M. H. Ismail, "Malaysian and Steiner waldorf science curricular practices: a comparative study and implications for the design of Science Teacher Education", STEM Planet Journal, 2014, 1, 1-12. in press.

[11] R. Andrews and R. Soder, "Principal leadership and student achievement", Educational Leadership, 1987, 44(6), 9-11. in press

[12] P. Casey, K. Dunlap, K. Brown and M. Davison, "Elementary principals' role in science instruction", Administrative Issues Journal Education Practice and Research, 2012, 2 (2), 57-62. in press.

[13] J. S. Peacock, "Science instructional leadership: the role of the department chair", SUMMER, 2014, 23,1, 36-48. in press.

[14] L. F. Gerard, J. B. Bowyer and M. C. Linn, "Principal leadership for technology-enhanced learning in science". Journal of Science Education and Technology, 2008, 17(1), 1-18. in press.

[15] P. Hallinger and J. Murphy, "Assessing the instructional management behavior of principals", The Elementary School Journal, 1985, 86(2), $217-247$, in press.

[16] J. Murphy, "Principal instructional leadership", In R. S. Lotto and P. W. Thurston (Eds.), Advances in educational administration: Changing perspectives on the school, Vol. I, Pt. B, Greenwich, CT, 1990, pp. 163200.

[17] P. Hallinger, "Instructional leadership and the school principal: a passing fancy that refuses to fade away." Leadership and Policy in Schools, $2005,4,3: 1-20$, in press

[18] M. Y. Ibrahim and W. A. A. Wan Mohammed Amin, "Amalan kepemimpinan pengajaran pengetua Terengganu", Kertas Kerja Persidangan Majlis Pengetua Sekolah-sekolah Malaysia Terengganu, Awana Kijal Golf \& Hotel, Kijal Kemaman, 25-26 September 2011.

[19] Checkmarket: sample size calculator. Available from: https://www. checkmarket.com/market-research-resources/sample-size-calculator [Accessed: 20 th June 2016].
[20] H. Pettiegrew II, "The perceptions of principal instructional leadership practices on 8th grade Ohio achievement assessment (OAA)", Doctor of Philosophy, Cleveland State University, 2013. unpublished.

[21] J. L. Owens, "Principal and teacher perceptions of instructional leadership and organizational health in secondary schools", Doctor of Education, Baker University, 2015.unpublished.

[22] A. L. Gumuseli, "İstanbul ilindeki ilköğretim okulu müdürlerinin öğretim liderliği davranışları. Yayınlanmamıș araştırma. Yıldız Teknik Üniversitesi, İstanbul, 1996. unpublished.

[23] S. Kapusuzoglu and A. I. Baysal, "Comparison of instructiona leadership behaviours of public and private primary education school administrators. Ozean Journal of Social Sciences, 2010, 3(1), 121-140. in press.

[24] J. Murphy and P. Hallinger, "New directions in the professional development of school administrators: A synthesis and suggestions for improvement". In J. Murphy \& P. Hallinger (Eds.), Approaches to administrative training in education, Albany, NY: SUNY Press, 1987, pp. 245-282.

[25] U. Jawas, "Instructional leadership in Indonesian school reform: local perceptions and practices", Doctor of Philosophy, University of Canberra, Australian Capital Territory, Australia, 2014. unpublished.

[26] P. Hallinger and R. H. Heck, R.H. "Reassessing the principal's role in school effectiveness: 1980-1995", Educational Administration Quarterly, 1996, 32(1), 5 -44. in press.

[27] V. Robinson "The impact of leadership on student outcomes: making sense of the evidence" Keynote address presented at the New Zealand Ministry of Education Research Conference, Auckland, New Zealand, 2007

[28] R. J. Marzano, T. Waters and B. A. McNulty, "School leadership that works. Alexandria", VA: Association for Supewision and Curriculum Development (ASCD), 2005.

[29] J. L. Brendan, "Principal Instructional Leadership Behavior as Perceived by Teachers and Principals at New York State Recognized and NonRecognized Middle Schools", Seton Hall University Dissertations and Theses, 2010, Available from: http://scholarship.shu.edu/cgi/view content.cgi?article $=2373 \&$ context $=$ dissertations $\quad[$ Accessed: 25 July, 2016].

[30] S. Maznah and M. Hussain, "Instructional leadership practices of the excellent school principals in Aceh, Indonessia: managing the instructional program", Available from: http://artsonline.monash.edu.au/ indonesian-studies-journal/files/2015/04/Instructional-leadershippractices.pdf. [Accessed: 23 th July 2016]

[31] P. Mendels, "The effective principal". February, 2012, 33,1, 54-58, Available from: http://www.wallacefoundation.org/knowledge-center/ Documents/The-Effective-Principal.pdf. [Accessed: 25 th July 2016]

[32] P. Hallinger and J. F. Murphy, "Instructional leadership in effective school”, 1986, ERIC (ED 309535), Available from: http://files. eric. ed.gov/fulltext/ED309535.pdf, [Accessed: 21 th July 2016].

[33] W. Hawley, "Teaching tolerance: strategies for reducing racial and ethnic prejudice: essential principles for program design", Available from: http://www.tolerance.org/ supplement/strategies-reducing-racialand-ethnic-prejudice-essential-pr, [Accessed: 22 th July 2016].

[34] K. Leithwood, K. S. Louis, S. Anderson and K. Wahlstrom, "Learning from leadership project: review of research how leadership influences student learning", University of Minnesota, University of Toronto and The Wallace Foundation, 2004.

[35] S. Huyer, "Addressing global challenges: focusing science, technology and innovation (STI) policy and funding through a gendered lens", Paris, France, UNESCO, 2010. 